ACTAA THERIOLOGICA

Vol. 218, 2: 25-32, 1983

\title{
Colour Patterns in Neomys anomalus
}

\author{
Iwona MICHALAK
}

Michalak I., 1982: Colour patterns in Neomys anomalns. Acta theriol, 28, 2: 25-32 [With 1 Table, 1 Fig. and Plate III].

Variability in the coloration of $N$. anomalus Cabrera, 1907 was examined for animals captured in the Białowieża Primeval Forest, Pomerania and Bieszczady mountains $(n=148)$. Colour marks were found in 21 specimens, including 11 with a stripe running aong the medial line of the belly, one with a patch on the throat, seven with a stripe and a patch occurring together, one with dark spots in the axillary region, and one specimen with a dark spot around th anus. In some parts of the fur of two captive shrews melanin was acking. A relationship was found between the size of white spots iround the eyes and the colour of the belly.

[Mammals Research Institute, Polish Academy of Sciences, 17-230 Białowieża, Poland].

\section{INTRODUCTION}

The belly fur is usually light in representatives of the genus Neomys. Forms with dark grey or dark brown undersides, which in extreme cases do not differ from the black dorsal surfaces in melanistic shrews, were less frequently met.

A relatively extensive amount of data exist on ccioration variability in Neomys fodiens (Pennant, 1977) particularly on the colour patterns of the ventral part (Kuntze, 1935 ; Dehnel, 1950 ; Giben, 1953 ; Kahmann \& Rössner, 1956 ; Bree et al., 1963 ; Lehmann, 1966; Borowski, 1973 ; Skarén, 1973; Jenkins, 1977; Fedyk \& Borowsk, 1980). Neomys anomalus, however, is characterized by a considerably lower variability in coloration. A description of colour patterns in N. anomalus is given only by Kuntze (1935) for shrews from the region of Seged, Moldavia, by Dehnel \& Borowski (1973) for animals from the Biłowieża Forest, by Bauer (1960) from Neusiedlersee, Austria, and by Liar \& Daan (1976) from French Ardennes.

Reining (1937, after Bauer 1960) distinguished two types of dark belly coloration in N. fodiens : (1) "nigrysm" - the sccurrence of dark fur on the flanks of the belly or on its whole surface, and (2) "abundysm" - the occurrence of dark marks on the ighter belly. Bauer (1960) has described different stages of nigrysm ani various kinds of abundysm. 
Nigrysm and abundysm occur frequently in $N$. fodiens, and in different, independent combinations. In Neomys anomalus only nigrysm has so far been recorded. The only case of abundysm is described by Bauer (1960).

The present paper describes the variability in the coloration of $N$. anomalus from the Białowieża Forest. Also the occurrence of abundysm is analysed for other populations of this species living in Poland.

\section{MATERIAL AND METHODS}

The material was divided into two categories with respect to its usefulness in the study on fur coloration. One category consists of 60 individuals caught in 1979-1981 in the Białowieża Forest. Fur coloration of these animals was determined in vivo. Two classes of the coloration of the ventral side were distinguished: light and dark. The light class consists of the animals with white or light grey bellies, while the dark class is made up of the animals with dark grey bellies (a "nigristic" type). In addition, colour marks on the belly ("abundysm") were noted, as well as white spots around the eyes. Also the colour of the belly is described for shrews born in captivity during 1980 .

The second category of material consists of pelts of $N$. anomalus caught in the Białowieża Forest in 1948-1976 $(n=67)$, in the Bieszczady mountains in 1964 $(n=9)$ and in Pomerania in $1966(n=12)$. This material was surveyed only with respect to colour marks. The reason for this was that some skins were obtained from animals kept in alcohol, and the fur colour was presumably changed. Also, it is not possible to estimate the size of white spots around the eyes on the preserved skin; they are clearly visible only on live animals.

\section{RESULTS}

\subsection{Coloration of N. anomalus Caught in the Bialowieża Forest in 1979-1981}

The dorsum of each of these animals was black. Dull fur occurred in young individuals, sexually immature, while glossy fur was characteristic of overwintered animals. In all the specimens the boundary between the dorsal and ventral parts was conspicuous. In general, the coloration of the dorsal side was consistent with the description given by Borowski (1973).

One shrew kept in captivity over the winter had anomalous coloration of the back. This animal started to moult in captivity in autumn. The summer fur on the back was black but the new winter pelage lacked pigment in the basal parts of the hairs, only the tips of the hairs being dark (Photo 1).

Individuals with lightly coloured bellies predominated $(n=57)$. In only three cases were the venters much darker: dark grey. These 
Table 1

Dark marks in $N$. anomalus.

\begin{tabular}{|c|c|c|c|c|c|}
\hline $\begin{array}{c}\text { Localit: } \\
\text { year, }\end{array}$ & $\begin{array}{l}\text { ty, } \\
\text { n }\end{array}$ & $\begin{array}{l}\text { Coll. } \\
\text { no. }\end{array}$ & $\begin{array}{l}\text { Kind of dark } \\
\text { stripe patch }\end{array}$ & $\begin{array}{l}\text { marks } \\
\text { stripe } \\
\text { \& patch }\end{array}$ & Intensity of dark marks \\
\hline $\begin{array}{l}\text { Białowieża } \\
1979-1981\end{array}$ & $\begin{array}{l}\text { Forest, } \\
60\end{array}$ & $\begin{array}{r}122 \\
123 \\
133 \\
179 \\
191 \\
60 \\
176 \\
140 \\
143\end{array}$ & $\begin{array}{l}+ \\
+ \\
+ \\
+ \\
+\end{array}$ & $\begin{array}{l}+ \\
+ \\
+ \\
+\end{array}$ & $\begin{array}{l}\text { conspicuous } \\
\text { faint } \\
\text { " } \\
\text { conspicuous } \\
\text { faint }\end{array}$ \\
\hline $\begin{array}{l}\text { Bialowieża } \\
1948-1970\end{array}$ & $\begin{array}{l}\text { Forest, } \\
67\end{array}$ & $\begin{array}{r}9618 \\
36094 \\
9832\end{array}$ & $\begin{array}{l}+ \\
+\end{array}$ & + & $\begin{array}{c}\text { conspicuous } \\
,\end{array}$ \\
\hline $\begin{array}{l}\text { Bieszczady } \\
1964,9\end{array}$ & Mts., & 41293 & + & & faint \\
\hline $\begin{array}{l}\text { Pomerania, } \\
1966,12\end{array}$ & & $\begin{array}{l}59927 \\
60565 \\
60579 \\
60454 \\
59952 \\
60006\end{array}$ & $\begin{array}{l}+ \\
+ \\
+\end{array}$ & $\begin{array}{l}+ \\
+\end{array}$ & $\begin{array}{l}\text { conspicuous } \\
\text { very faint } \\
\text { " } \\
\text { small patch } \\
\text { faint stripe and very } \\
\text { small patch }\end{array}$ \\
\hline
\end{tabular}

shrews could be readily distinguished from the other specimens also with grey bellies but much lighter. No melanistic forms were recorded.

In 11 individuals $(18.3 \%)$ dark marks occurred on the lighter belly (Table 1, Fig. 1). Among them the following patterns of abundystic coloration could be distinguished: a longitudinal stripe in the medial part of the belly ( $n=5$, Pl. III, Photo 3$)$, a stripe and a patch on the throat $(n=4$, Photos 1 and 4$)$, axillary dark spots $(n=1$, Photo 5$)$, and

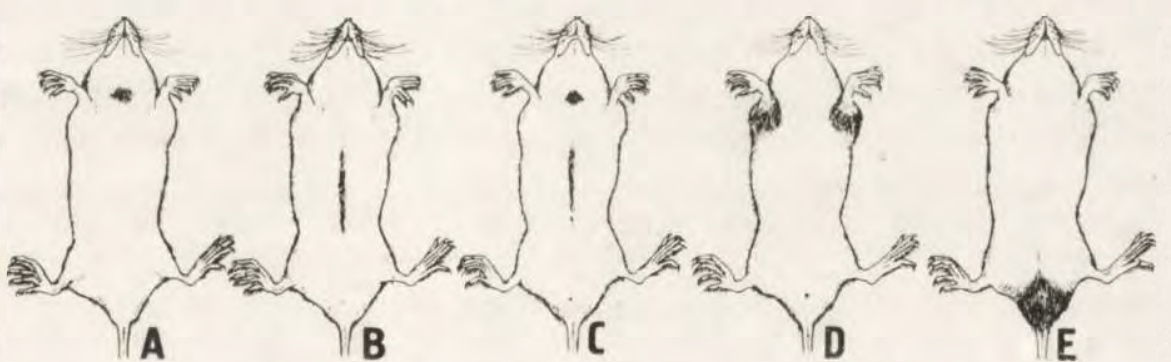

Fig. 1. Types of "abundysm" in N. anomalus.

A - a patch on the throat, B-a medial belly stripe, C-a patch and a stripe, $\mathrm{D}$ - dark axillary spots, $\mathrm{E}-\mathrm{a}$ spot around the anus. 
a dark spot on the posterior ventral surface, around the anus $(n=1)$. In one case dark marks occurred on the dark belly (a patch and a stripe), and in all the other cases they occurred on the light belly. One shrew with white belly had a dark perianal spot and another had dark axillary spots.

A relationship was found between the shades of grey on the venter side and the size of white spots around the eyes. In the shrews of the light class, the fur of which was slightly darker (light grey), and in three individuals of the dark class, the "eye spots" were much smaller than in shrews with very light bellies. As a rule, white belly was coupled with large white spots near the eyes. In the shrews with colour marks, the spots around the eyes were small. In two light grey individuals with colour marks, no "eye spots" were recorded. One specimen with a dark perianal patch possessed a white belly and very conspicuous, large "eye spots".

\subsection{Coloration of $\mathbf{N}$. anomalus Born in Captivity}

Two litters were born in captivity to the same parents. The male and the female had white bellies and large white spots in the eye region. The first litter consisted of five young, of which four ( 1 male, 3 females) were weaned. All of them were of the colour of their parents. In the second litter (1 male and 1 female) the young male was identical in coloration to that of his parents; the female had an irregular white spot clearly visible on the light belly (Photo 2), completely devoid of pigment.

3.3. Coloration of N. anomalus Collected from the Bialowieża Forest in 1948-1976, from the Bieszczady Mountains and from Pomerania

In shrews of these populations, three types of colour marks were recorded: a stripe $(n=6)$, a stripe and a patch $(n=3)$, and a patch $(n=1)$ (Table 1). The last pattern did not occur in material from the Białowieża Forest in 1979-1981. However, it cannot be stated with certainty that this specimen lacked a stripe, since the skin was cut along a midventral line.

\section{DISCUSSION}

The variability of colour patterns in $N$. anomalus is much greater than previously reported. There are not melanistic forms, as only in three cases the fur of the belly was dark grey (1979-1981 Białowieża 
Forest material). These three were not melanistic since the boundary between the dorsum and venter was clear-cut, though the belly fur was dark. Melanistic shrews have however been caught in the Białowieża Forest (Dehnel, 1950).

Special attention should be paid to the fact that 21/148 specimens had dark marks on light bellies. Identically located dark marks have so far been described only for $N$. fodiens. Apparently only Bauer (1960) found a single $N$, anomalus with a small dark patch on the throat. A question arises whether the lack of literature data on the occurrence of abundysm in $N$. anomalus from other populations provides evidence for a unique coloration of this species in Poland. Some data suggest that the material examined was not unique. First, the shrews derived from different study plots and from three different allopatric populations. Thus this is not a case of a local, isolated population in which a character excluded from other populations could emerge by genetic drift.

Second, dark marks in $N$, anomalus are not as large as in $N$. fodiens. They are less clear-cut and sometimes so delicate that they can be overlooked at a superficial examination of belly fur. For example, earlier studies of $N$. anomalus in the Białowieża Forest, carried out in 1948 - 1970, did not reveal the occurrence of Mediterranean water shrews with colour marks (Dehnel, 1950; Borowski, 1973). Only the reexamination of the portion of this material, made up of 67 from 247 pelts (contracted skins obtained from specimens kept in alcohol are not suitable for the analysis of this kind), revealed three specimens with ventral colour marks (Table 1). Most of these 67 pelts were cut along the medial line of the body, where the strips usually occur. This could account for overlooking a delicate ventral mark, and obviated estimation of colour marks frequency. It is noteworthy, however, that colour-marked Mediterranean water shrews have not appeared in the Białowieża Forest in recent years, although they occurred there earlier (two specimens in 1949 and one in 1964). A high frequency of $N$. anomalus with colour marks is evidenced in the Białowieża Forest sample of $1979-1981(18.3 \%)$. Also, surprisingly high numbers of colour-marked $N$. anomalus occur in the Pomeranian population (6/12). Therefore, the occurrence of colour marks in $N$. anomalus is not sporadic.

It is possible that size of white "eye spots" and ventral grey shading are genetically linked, such that large white "eye spots" may be inherited with the light belly coloration. This hypothesis is supported by the fact that a similar correlation was recorded in $N$. fodiens (Michalak, 1983).

There is some doubt concerning the two described cases of depigmen- 
tation in some parts of the fur (a female with a white spot on the belly, and a male with light fur on the back). It should be remembered that these coloration anomalies occurred in captive animals. It is possible that the laboratory conditions, e.g., deficiency of some nutrients in the food supplied, accounted for this lack of pigments.

\section{REFERENCES}

1. Bauer K., 1960: Die Säugetiere des Neusiedlersee-Gebietes. Bonn. zool. Beitr., 11: $141-344$.

2. Borowski S., 1973: Variations in coat and coat colour in representatives of the genus Sorex L. and Neomys Kaup. Acta theriol., 18: 247-279.

3. Bree P.J.H. van, Chanudet F. \& Saint Girons M. C., 1963: Notes sur des colorations anormales chez les musaraignes (Insectivora, Soricidae). Mammalia, 27 : $300-305$.

4. Dehnel A., 1950: Studies on the genus Neomys Kaup. Annals Univ. M. CurieSkłodowska, C, $5: 1-63$.

5. Fedyk S. \& Borowski S., 1980: Colour variants in the Białowieża population of European water shrew. Acta theriol., 25: 3-24.

6. Giban J., 1956: A propos de la capture de deux crossopes aquatiques aux environs de Versailles. Mammalia, 20:57-65.

7. Jenkins P.D., 1977: Genus Neomys. [In: "Handbook of British Mammals", Corbet G. B., Southern H.N. Eds]. Blackwell Sci. Publ. : 57-61. Oxford.

8. Kahmann H. \& Rössner F.X., 1956: Die Natur der Färbungsvielgestaltigkeit der Unterseide bei der Wasserspitzmaus (Neomys). Naturwissenschaften, $43: 46$.

9. Kuntze R., 1935: Ssaki (Mammalia). ["Fauna słodkowodna Polski"]. Wydawnictwo Kasy im. Mianowskiego, 2: 1-72. Warszawa.

10. Laar V. van \& Daan N., 1976: Neomys anomalus Cabrera, 1907, observé dans les Ardennes francaises. Lutra, 18: $44-51$.

11. Lehmann E. von, 1966: Anpassung und "Lokalkolorit" bei den Soriciden zweier linksrheinisches Moore. Säugetierkdl. Mitt., 2: 127-135.

12. Michalak I., 1983: Ubarwienie Neomys fodiens (Pennant, 1771), dziedziczenie piętn barwnych brzucha. Acta theriol., (in preparation).

13. Skarén U., 1973: Aberrant colour of shrew (Sorex araneus L. and Neomys fodiens Schreb.) in Finland. Säugetierkdl. Mitt., 21: 74-75.

Accepted, December 21, 1982.

Iwona MICHALAK

\section{WZORCE UBARWIENIA U NEOMYS ANOMALUS}

\section{Streszczenie}

Zbadano zmienność ubarwienia 148 Neomys anomalus pochodzących z Puszczy Białowieskiej, Bieszczadów i Pomorza. U 21 osobników stwierdzono występowanie 
piętn barwnych na jaśniejszym tle brzucha: 11 osobników posiadało pręgę pośrodku brzucha, 1 łatkę na podgardlu, 7 pręgę i łatkę występujące razem, 1 ciemne plamy pod pachami, 1 ciemną plamę w okolicy anus (Tabela 1, Ryc. 1). Opisano dwa przypadki wystąpienia braku melanin w części uwłosienia: samiec z jasno ubarwionym grzbietem, samica $\mathrm{z}$ białą plamą na brzuchu (Fot. 1, 2). Stwierdzono istnienie odwrotnej zależności między stopniem szarości brzucha a wielkością biaiych plamek przy oczach. 
EXPLANATION OF PLATE

Plate III

Photo 1. A male (coll. no. 60) with light fur on the back, with a stripe and a patch on the belly.

Photo 2. A female (coll. no. 73a) with a light spot on the belly. Photo 3. A female (coll. no. 133) with a stripe.

Photo 4. A female (coll. no. 143) with a stripe and a patch.

Photo 5. A female (coll. no. 32) with dark axillary spots. 
ACTA THERIOLOGICAL, Vol. XXVIII, 2.

Plate III.

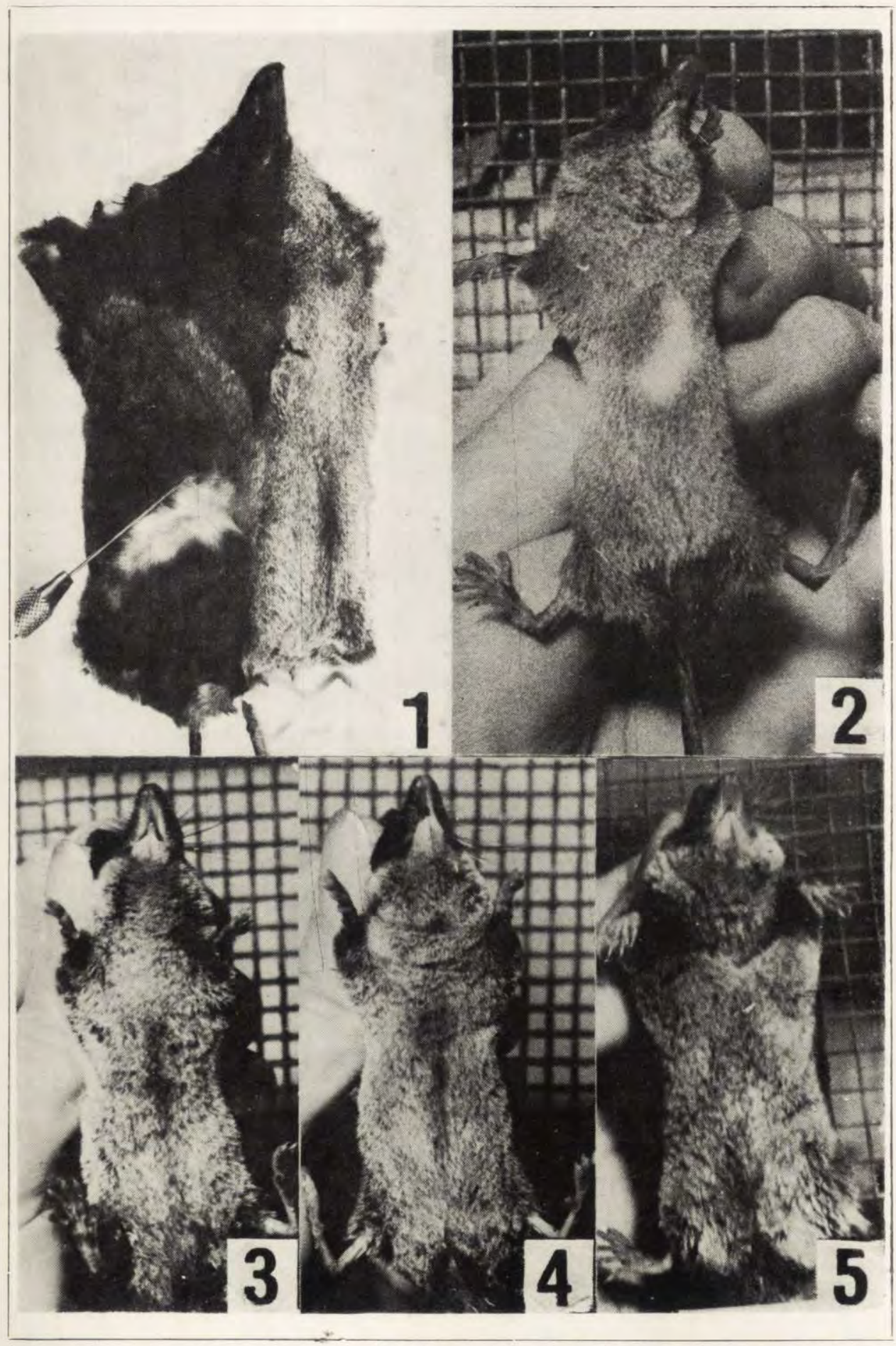

J. Michalak

S. Buszko phot. 